\title{
Brucella seropositivity in chicken and risk factors for Brucella infection at the animal-human interface in Anambra State, Nigeria
}

\author{
Joseph Ikechukwu Onunkwo ${ }^{1}$, Emmanuel Okechukwu Njoga ${ }^{1}$, Ugochinyere Juliet Njoga ${ }^{2}$, Emmanuel Ezeokafor ${ }^{1}$ and
} Samuel Okezie Ekere ${ }^{2}$

1. Department of Veterinary Public Health and Preventive Medicine, University of Nigeria, Nsukka; Enugu, Nigeria;

2. Department of Veterinary Obstetrics and Reproductive Diseases, University of Nigeria, Nsukka; Enugu, Nigeria.

Corresponding author: Emmanuel Okechukwu Njoga, e-mail: njoga.emmanuel@unn.edu.ng

Co-authors: JIO: joseph.onunkwo@unn.edu.ng, UJN: ugochinyere.njoga@unn.edu.ng,

EE: ezeokoaforec@gmail.com,SOE: samuel.ekere@unn.edu.ng

Received: 30-04-2018, Accepted: 24-05-2018, Published online: 24-06-2018

doi: 10.14202/IJOH.2018.28-34 How to cite this article: Onunkwo JI, Njoga EO, Njoga UJ, Ezeokafor E, Ekere SO. Brucella seropositivity in chicken and risk factors for Brucella infection at the animal-human interface in Anambra State, Nigeria. Int J One Health 2018;4:28-34.

\begin{abstract}
Aim: Brucellosis is an important bacterial zoonosis devastating both animal and human populations in many parts of the world. A seroepidemiological study of avian Brucella infection was conducted to determine the disease prevalence, risk factors, and hence the role of chicken in the epidemiology of brucellosis in Anambra State, Nigeria.

Materials and Methods: Rose Bengal plate test was used to test for Brucella antibody in sera samples collected from 410 chickens surveyed. The interview schedule was used to elicit information on the socioeconomic status, awareness of brucellosis and predisposing practices of poultry farmers, live bird sellers, and poultry carcass processors in the study area.

Results: An overall seroprevalence of 3\% was recorded. Sex (female), free-range management system, breed (indigenous breed), and mix farming were the determinants of avian brucellosis in the state. Risk factors that may enhance human Brucella infection at the animal-human interface are non-use of personal protective clothing; poor awareness on brucellosis and methods of the disease spread or control, cohabitation with animals, and eating while on duty.

Conclusion: Chicken may be among the reservoirs of Brucella infection in Anambra State. There is an urgent need for an effective control program against brucellosis in the study area, using a coordinated One Health approach bearing in mind the public health and economic consequences of brucellosis.
\end{abstract}

Keywords: Brucella antibodies, Brucella infection, Brucella, chickens, humans, risk factors.

\section{Introduction}

Brucellosis is a pervasive zoonosis greatly dreaded worldwide because of its negative impacts on humans' health and wealth. Brucella organisms, the agents of brucellosis, are Gram-negative, aerobic, and facultative intracellular pathogens; which are small sized $(0.5-0.7 \mu \mathrm{m} \times 0.6-1.5 \mu \mathrm{m})$, non-motile, nonsporulating, and nonencapsulated [1]. Although many Brucella species have been described; Brucella abortus, Brucella melitensis, Brucella suis, Brucella ovis, and Brucella canis are known Brucella pathogens, preferentially infecting cattle, goats, pigs, sheep, and dogs, respectively [2]. About $90 \%$ of animal and human brucellosis worldwide are caused by only $B$. melitensis, B. abortus, and B. suis [3]. Chicken is susceptible to both $B$. melitensis and B. abortus [4-7] and probably $B$. suis. The pathogenic capabilities of Brucella organisms depend on the presence (smooth) or absence (rough) of O-polysaccharide side chain,

Copyright: Onunkwo, et al. This article is an open access article distributed under the terms of the Creative Commons Attribution 4.0 International License (http://creativecommons.org/licenses/ by/4.0/), which permits unrestricted use, distribution, and reproduction in any medium, provided you give appropriate credit to the original author(s) and the source, provide a link to the Creative Commons license, and indicate if changes were made. The Creative Commons Public Domain Dedication waiver (http:// creativecommons.org/ publicdomain/zero/1.0/) applies to the data made available in this article, unless otherwise stated. a lipopolysaccharide moiety, at the outer membrane of the bacterial cell wall [8]. While the rough species (B. ovis and B. canis) are moderately pathogenic to animals, the smooth species (B. melitensis, B. abortus, and $B$. suis) are highly virulent [8] causing severe disease in both humans and animals.

Although brucellosis has a cosmopolitan distribution (except in Antarctica where there is no reported case), the disease burden is more in tropical and developing countries [9]; where the synergy of climatic conditions and inefficient disease control measures generally facilitate the odds and endemicity of most infectious diseases [10]. In Nigeria, avian brucellosis was first reported in local chicken as "Chiwon Bakale" in Mambilla, Plateau State in 1982 [6], and Anambra State in 1988 [7]. Since then, the disease has continued to devastate both humans and animals in the country; causing enormous economic losses in animal agriculture [11] and significant health problems in humans $[3,12,13]$, especially among individuals occupationally exposed to brucellosis. About 90\% of global brucellosis cases occur in resource-limited developing countries or tropical climatic regions of the world $[14,15]$; where livestock production is incidentally a major means of livelihood $[10,14]$.

Brucellosis in animals is transmitted through coitus or use of infected semen during artificial 
insemination, inhalation of aerosolized Brucella agents, ingestion of tissues or discharges from infected animals, in vivo or in vitro maternal transfer to fetus, and lactation by infected dam [14-17]. In livestock, the disease manifests as middle or late-term abortion, birth of unthrifty neonates, retained placenta, reduced milk yield, repeat breeder syndrome, increased parturition interval, lameness due to polyarthritis, orchitis, and epididymitis in males $[16,17]$. In chicken, especially those on extensive (free range) production system, the common ways of acquiring Brucella infection is by pecking on the vent of infected chicken, aborted fetuses or after birth materials expelled by infected animals [18-20]. The disease may also be transmitted in avian species through mating or use of infected semen or equipment during artificial insemination $[19,20]$; and through inhalation [18,19] especially in overstocked poultry houses or settings where different animal species are reared in very close proximity that permits inhalation of Brucella agents from an infected animal.

Brucella agents cause significant public health problem due to their enormous zoonotic capabilities. Consumption of infected raw or undercooked animal products such as eggs, milk, and meat is the most important means of Brucella transmission in humans [21]. Zoonotic transmission of the disease can also occur through inhalation [22] in overcrowded areas where animals cohabit with human and through contamination of wound with infected fluid or tissue; especially among occupationally exposed individuals [23]. However, use of personal protective clothing (PPC) during routine operations, may significantly reduce the rate of Brucella infection. The public health consequence of brucellosis is not only due to the zoonotic transmission of the disease but also because it causes a serious diminution of animal proteins, particularly in developing countries where available animal protein fall short of the need or demand of the populace.

In humans, brucellosis manifests mainly as an undulating fever, but with serious debilitating complications, that may necessitate prolonged therapy with antibiotic combinations [24]. Human brucellosis is often misdiagnosed as malaria or typhoid fever due to the difficulty in clinically differentiating the disease from other febrile conditions [25]. There is no vaccination program against human brucellosis, and human-to-human transmission of the disease has not been documented [25]. B. melitensis, B. abortus, and $B$. suis are major species responsible for more than 500,000 human cases of brucellosis reported annually worldwide [26]. Rare cases of human brucellosis caused by $B$. canis have been reported, but the human disease caused by $B$. ovis and B. neotomae have not been documented [26]. Successful control of brucellosis in animal populations and full compliance to workplace and food safety practices are indispensable for effective control of the human disease; because almost all cases of human brucellosis are acquired from animals $[27,28]$.

Apart from the public health problems, brucellosis also affects human's wealth adversely. The economic significance of brucellosis rests on the ability of the Brucella agents to cause reproductive and infertility problems in animals such as abortion, increased parturition intervals, repeat breeder syndrome [29], and decreased egg production in chicken [30]. Overwhelming, economic losses may accrue from costs of medical treatment or veterinary care, prevention or control measures against the disease, biosecurity measures in farms, and restrictions in animal trade or their products [29]. Abortion is the most important clinical manifestation responsible for economic losses in animal agriculture. Infected animals may abort only once but remain carriers for life, effectively discharging large amounts of the disease agent (up to $10^{10} \mathrm{per} \mathrm{g} / \mathrm{ml}$ of infected tissue or fluid) into the environment for onward transmission to humans or other animals [31].

Although there are many reports on seroprevalence of Brucella antibodies in other food animals in Nigeria $[2,8,12,16,17,22]$, there is a dearth of information on avian brucellosis and the disease determinants in the study area. Chicken may be important in the epidemiology of Brucella infections in the state as it is usually reared together with other food animals. Close chicken-livestock-human contact may enhance the disease spread and interspecies exchange of Brucella organisms. These accentuate the need to investigate the disease prevalence and its determinants in chicken in the study area.

The aim of the study was, therefore, to determine Brucella seropositivity in chicken and also the risk factors for Brucella infection, especially at the animal-human interface in Anambra State; to proffer epidemiological solution to limit the disease spread and its untoward public health and economic implications.

\section{Materials and Methods}

Ethical approval

Ethical approval is not applicable to this study as blood samples used for brucellosis screening were sourced from slaughtered chickens at poultry abattoirs.

\section{Informed consent}

Oral consent to participate in the survey was sought and obtained from all individuals included in the study. Consequently, 114 respondents were randomly selected from those who consented to participate in the survey and were therefore interviewed.

\section{Study area}

The study was carried out in Anambra State, Nigeria, with map coordinates $6^{\circ} 20^{\prime} \mathrm{N} 7^{\circ} 00^{\prime} \mathrm{E}$; a total land area of $4844 \mathrm{~km}^{2}$ and a population of about $6.8 \mathrm{mil}-$ lion people. Majority of the citizenry were engaged in buying and selling businesses, but backyard food animal (poultry and small ruminants) production is widely practiced as sources of additional family income. 


\section{Blood sample collection and screening}

Research visits were made to three major poultry abattoir in the study area for blood sample collection. Samples were collected weekly over a period of 6 months; consisting of 3 months of dry season (February to April) and another 3 months of rainy season (June-August). Simple random sampling method was used to select five poultry slaughter points (from those who consented to participate in the study) per abattoir for sampling. Systematic sampling method was employed in the selection of chickens sampled at each slaughter pointed selected. The sex and breed of each selected chicken were determined by visual examination, but the type of husbandry systems in which the sampled chicken was reared was ascertained from the animal owners. About $5 \mathrm{ml}$ of blood was collected per chicken from the severed jugular vein immediately after bleeding. The blood samples were allowed to clot and then centrifuged at $4000 \mathrm{rpm}$ for $10 \mathrm{~min}$. Serum samples formed were harvested and screened for Brucella antibody using Rose Bengal Plate Test (RBPT) according to the method described by Alton et al. [1].

\section{Data collection on risk factors for human Brucella infection}

Interview schedule was used to obtain information on socioeconomic status and risk factors for human Brucella infection from 114 randomly selected occupationally exposed respondents (poultry farmers, live bird sellers, and poultry carcass processors). The survey was conducted in the native language to respondents who were not proficient in using the English language. Thereafter, the responses were collated and statistically analyzed.

\section{Statistical analysis}

Chi-square statistic was used to test for the association $(\mathrm{p}<0.05)$ between the occurrence of Brucella antibodies and sex, breed, season, and management system. The test was also used to check for the association $(p<0.05)$ between the educational levels of the respondents and knowledge of brucellosis and involvement in practices that predispose to Brucella infection. The tests were performed at 5\% probability level using IBM ${ }^{\circledR}$ SPSS statistic version 20 (SPSS Inc., Chicago, Illinois, USA).

\section{Results}

\section{Seroprevalence of Brucella antibodies in chicken}

Results of distribution of Brucella antibodies in chicken $(n=410)$ according to sex, season, breed, and farm management systems in Anambra State,
Nigeria, are presented in Tables-1-4, respectively. Seroprevalence of $7.14 \%$ and $2.01 \%$ was recorded for the female (hen) and male (cock) chickens, respectively, but the odds of brucellosis was about 4 times higher in females than in males (Table-1). Similarly, a seroprevalence of $4.46 \%$ was recorded during the wet (rainy) season (Table-2) while Brucella antibodies were detected more in indigenous (6.97\%) than in exotic $(0.84 \%)$ breeds of birds screened (Table- 3$)$. Birds under extensive management system yielded $7.27 \%$ seroprevalence as against $1.98 \%$ and $2.08 \%$ recorded for birds reared under intensive and semi-intensive management systems, respectively (Table-4). Chi-square statistic revealed a significant association $(\mathrm{p}<0.05)$ between Brucella seropositivity and sex, breed, and management system but no significant association $(p>0.05)$ was found between the occurrence of the antibodies and season at $\mathrm{p}=0.339$.

\section{Result of the interview schedule}

Information on the socioeconomic status, knowledge of brucellosis, and use of PPC among poultry farmers, live bird sellers, and poultry carcass processors are presented in Table-5. Notable risk factors, behaviors and practices that can enhance human Brucella infection documented are rearing of poultry and other animal species in the same household or farm, paltry level of education, poor knowledge or awareness of brucellosis and the dynamics of the diseases spread, cohabitation with animals at nights to prevent theft, eating while on duty and non-use of PPC.

The majority $78(68.4 \%)$ of the respondents were poultry farmers who also reared other food animals such as goats, pigs, and sheep (Table-5). About 11\% of the respondents had no formal education while $79.8 \%$ had no knowledge of brucellosis. Most (53.5\%) of the respondents cohabitated with their domestic animals at nights to prevent theft while $69.2 \%$ of them had been eating while on duty (Table-5). Only $15.5 \%$ of the respondents use PPC during their routine operations (Table-5). There were significant associations $(p<0.05)$ between the educational levels and knowledge of brucellosis, use of protective clothing during routine duties, cohabitation with animals at night and eating while on duty (Table-6).

\section{Discussion}

The overall 3\% seroprevalence recorded in this study shows that avian brucellosis continues to persist in Anambra State, Nigeria, even after about three decades when the first evidence of Brucella infection

Table-1: Sex distribution of Brucella antibodies in chickens $(n=410)$ in Anambra state, Nigeria.

\begin{tabular}{|c|c|c|c|c|c|c|c|}
\hline Sex & Number screened & Number positive & Seroprevalence & Odds ratio & $95 \% \mathrm{CI}$ & $\chi^{2}$ value & p value \\
\hline Female & 112 & 8 & 7.14 & 3.744 & $1.269-11.045$ & 6.494 & 0.011 \\
\hline Male & 298 & 6 & 2.01 & & & & \\
\hline Total & 410 & 14 & 3.41 & & & & \\
\hline
\end{tabular}

$\mathrm{CI}=$ Confidence interval 
Available at www.onehealthjournal.org/Vol.4/5.pdf

Table-2: Seasonal distribution of Brucella antibodies in chickens $(n=410)$ in Anambra state, Nigeria.

\begin{tabular}{|c|c|c|c|c|c|c|c|}
\hline Seasons & Number screened & Number positive & Seroprevalence & Odds ratio & $95 \% \mathrm{CI}$ & $\chi^{2}$ & pvalue \\
\hline Dry & 186 & 4 & 2.15 & 0.453 & $0.86-2.39$ & 0.914 & 0.339 \\
\hline Wet & 224 & 10 & 4.46 & & & & \\
\hline Total & 410 & 14 & 3.41 & & & & \\
\hline
\end{tabular}

$\mathrm{CI}=$ Confidence interval

Table-3: Breed distribution of Brucella antibodies in chickens $(n=410)$ in Anambra state, Nigeria.

\begin{tabular}{|c|c|c|c|c|c|c|c|}
\hline Breed & Number screened & Number positive & Seroprevalence & Odds ratio & $95 \% \mathrm{CI}$ & $\chi^{2}$ & pvalue \\
\hline Exotic & 238 & 2 & 0.84 & 0.107 & $0.013-0.909$ & 6.059 & 0.014 \\
\hline Indigenous & 172 & 12 & 6.97 & & & & \\
\hline Total & 410 & 14 & 3.41 & & & & \\
\hline
\end{tabular}

$\mathrm{CI}=$ Confidence interval

Table-4: Distribution of Brucella antibodies in chickens $(n=410)$ according to farm management systems in Anambra state, Nigeria.

\begin{tabular}{|c|c|c|c|c|c|}
\hline Management systems & Number screened & Number positive & Seroprevalence & $\chi^{2}$ & p-value \\
\hline Intensive & 156 & 3 & 1.92 & 6.791 & 0.034 \\
\hline Semi-intensive & 144 & 3 & 2.08 & & \\
\hline Extensive & 110 & 8 & 7.27 & & \\
\hline Total & 410 & 14 & 3.41 & & \\
\hline
\end{tabular}

in chicken in the study area was reported by Chukwu and Anene [7]. Detection of the same seroprevalence (3\%) initially reported about 30 years ago in both indigenous and exotic breeds reared under different husbandry management systems; points to the fact that the disease may have remained unabated probably due to defective intervention measures against the disease. Since there is currently no vaccination program against avian brucellosis in Nigeria, it is most probable that the antibodies detected in positive reactors were due to natural infection with Brucella agents.

The 3\% seroprevalence is significant because brucellosis can cause devastating human health problems and huge economic losses in animal agriculture. Infected chickens could serve as reservoirs of the infection for other chickens, livestock, and humans around the neighborhood as the infection could spread through chicken feces $[5,19,20,30]$. Tremendous amounts of Brucella agents, up to $10^{10} \mathrm{CFU} / \mathrm{g}$ of feces, are discharged into the environment by infected chicken $[31,32]$. In the study area, chicken feces are commonly used as manure in agrarian communities or for feeding of pigs, pound fish, or fertilization of fish pounds during conditioning. This practice greatly enhances the spread of Brucella infection and may worsen the problem of environmental contamination with Brucella agents as the organisms may be inhaled as an aerosol during gathering or application of chicken feces as manure or feed [5]. Eggs from infected chicken may also transmit the infection, especially if not well cooked or if the basic hygienic practices guiding food preparation are ignored. The discharged organisms may contaminate pastureland used for grazing of ruminants reared alongside chicken in the same environment. Consequently, ruminants may be infected through grazing.
Furthermore, infected chickens are sources of infection to humans who are occupationally exposed to brucellosis or have very close contact with chicken. Considering the fact that most $(69.2 \%)$ of the respondents surveyed ate while on duty, contamination of cooking utensils and food items with Brucella agents from the droppings of infected chicken may give rise to Brucella infection of the entire household if the utensils are not properly washed or the contaminated food items not discarded.

Farmers and livestock reared in close proximity with Brucella infected chicken may transmit the infection across and within species and farms/neighborhood especially among those that practice mixed farming. Household members and occupationally exposed individuals may acquire Brucella infection through direct or indirect contact with infected tissues or fluids, contamination of wounds, skin cuts or abrasions; inhalation of infectious aerosols and accidental ingestion of infected materials [32]. This is particularly true in Anambra State in view of the fact that most of the respondents at risk of the infection did not use PPC (71.1\%), had paltry level (no formal or primary) of education (47.3\%), had poor knowledge of brucellosis and hence the dynamics of the disease spread or prevention $(79.8 \%$ ), cohabitated with their animals to prevent night theft $(53.5 \%)$ and ate while on duty $(69.2 \%)$.

Beside the zoonotic problems, the economic consequence of avian brucellosis is also noteworthy. Brucella organisms have been reported to cause decreased egg production, mortalities, decreased hatchability, general un-thriftiness, and infertility problems in poultry farms $[5,7,18-20]$. This is a major drawback to the production of much-needed animal protein, especially in rural settings where animal 
protein need of the people lags behind the supply. The resultant economic losses may impact negatively on the socioeconomic status of the farmers who ventured into poultry keeping to augment family income. In addition, the costs of medical treatments, veterinary

Table-5: Socioeconomic characteristics, awareness of brucellosis and risk factors for Brucella infection among respondents* $(n=114)$ surveyed in Anambra state, Nigeria.

\begin{tabular}{|c|c|}
\hline Information required & $\begin{array}{l}\text { Number }(\%) \text { of } \\
\text { respondents }\end{array}$ \\
\hline \multicolumn{2}{|l|}{ Gender } \\
\hline Male & $63(55.3)$ \\
\hline Female & $51(44.7)$ \\
\hline \multicolumn{2}{|l|}{ Occupation } \\
\hline Poultry farmers & $78(68.4)$ \\
\hline Life bird sellers & $15(13.2)$ \\
\hline Poultry carcass processors & $21(18.4)$ \\
\hline \multicolumn{2}{|c|}{$\begin{array}{l}\text { Other animals species reared in farms } \\
\text { visited }^{++}\end{array}$} \\
\hline Goats & $56(62.9)$ \\
\hline Pigs & $21(23.6)$ \\
\hline Sheep & $12(13.5)$ \\
\hline \multicolumn{2}{|c|}{$\begin{array}{l}\text { Highest educational qualification } \\
\text { attained }\end{array}$} \\
\hline No formal education & $12(10.5)$ \\
\hline Primary education & $42(36.8)$ \\
\hline Post-primary education & $39(34.2)$ \\
\hline Tertiary education & $21(18.4)$ \\
\hline \multicolumn{2}{|c|}{ Occupational experience (years) } \\
\hline$<5$ & $43(37.7)$ \\
\hline $5-10$ & $58(50.9)$ \\
\hline$>10$ & $13(11.4)$ \\
\hline \multicolumn{2}{|l|}{ Awareness on brucellosis } \\
\hline Yes & $23(20.2)$ \\
\hline No & $91(79.8)$ \\
\hline \multicolumn{2}{|c|}{$\begin{array}{l}\text { Cohabitation with animals at nights to } \\
\text { prevent theft }\end{array}$} \\
\hline Yes & $61(53.5)$ \\
\hline No & $53(46.5)$ \\
\hline \multicolumn{2}{|l|}{ Eating while on duty } \\
\hline Yes & $79(69.2)$ \\
\hline No & $35(30.7)$ \\
\hline \multicolumn{2}{|c|}{$\begin{array}{l}\text { Use of protective clothing while on } \\
\text { duties }^{++}\end{array}$} \\
\hline Yes & $18(15.8)$ \\
\hline No & $81(71.1)$ \\
\hline No response & $15(13.2)$ \\
\hline
\end{tabular}

*Respondents=Poultry farmers, live bird sellers, and poultry carcass processors, ${ }^{++}$Some respondents reared more than one food animal species care, biosecurity, and other interventions against the disease may exacerbate the economic losses and the econometrics of the poultry farming business.

The overall seroprevalence of 3\% recorded for avian Brucella infection in this study is comparatively lower than the findings of Kudi et al. [20], Ior et al. [5], and Adamu et al. [4] who reported seroprevalence of $30 \%, 10.9 \%$, and $10 \%$, respectively, in different parts of Nigeria. However, in Botswana, the 3\% seroprevalence is $>0.67 \%$ and $0.9 \%$ reported, respectively, by Gugong et al. [19] and Samakabadi et al. [31]. The differences in the findings from various study areas may be associated with disparities in epidemiological and environmental factors such as husbandry practices, extent of feed or water contamination with Brucella organisms, climatic conditions, source of replacement stock, the disease prevalence in other species, type of brucellosis diagnostic test performed, human errors in interpretation of the test results, and overall number of samples collected and tested.

Higher Brucella seropositivity in hens (7.14\%) than cocks $(2.01 \%)$ suggests that the females may be foci of avian Brucella infections in Nigeria since our finding agrees with that of Junaidu et al. [11] and Adamu et al. [4] who reported $2.6 \%$ and $4 \%$ seroprevalence in female chicken tested by RBPT in Borno and Sokoto States, Nigeria, respectively. Brucella species have affinity for the female reproductive organ due to the production of erythritol, a 4-carbon sugar in these tissues that stimulate their growth and proliferation [33]. Moreover, female chicken is generally reared for longer periods in the farm than cocks. The extended rearing period exposes females to higher chances of being infected with Brucella agents and hence the likelihood of acquiring the infection much more than the males.

Apart from sex, husbandry management system and breed of chicken seem to be important factors in the epidemiology of avian Brucella infection in the study area as indigenous breeds reared under extensive (free range) husbandry system yielded more Brucella antibodies than others. Free-range method of poultry production gives chickens the opportunity to mix freely with other animals (cattle, pigs, sheep, and goat) which may be harboring Brucella organisms. As

Table-6: Association between educational levels, knowledge of brucellosis, and predisposing practices to Brucella infection among respondents** $(n=114)$ surveyed in Anambra state, Nigeria.

\begin{tabular}{|c|c|c|c|c|}
\hline \multirow{2}{*}{$\begin{array}{l}\text { Educational levels } \\
\text { (number of respondents) }\end{array}$} & \multicolumn{4}{|c|}{ Number of yes respondents } \\
\hline & $\begin{array}{l}\text { Knowledge of } \\
\text { brucellosis }\end{array}$ & $\begin{array}{l}\text { Used protective } \\
\text { clothing }\end{array}$ & $\begin{array}{c}\text { Cohabitation with domestic } \\
\text { animals }\end{array}$ & $\begin{array}{l}\text { Eating while on } \\
\text { duty }\end{array}$ \\
\hline No formal education (12) & 2 & 1 & 10 & 9 \\
\hline Primary (42) & 5 & 2 & 29 & 33 \\
\hline Post-primary (39) & 5 & 4 & 17 & 28 \\
\hline Tertiary (21) & 11 & 11 & 5 & 9 \\
\hline Total (114) & 23 & 18 & 61 & 79 \\
\hline $\mathrm{p}$ & $0.001 *$ & $0.000 *$ & $0.001 *$ & $0.031 *$ \\
\hline
\end{tabular}

**Respondents=Poultry farmers, live bird sellers, and poultry carcass processors, *Denotes statistically significant Chi-square $\mathrm{p}$ values 
the animals graze, they may contaminate the environment with Brucella agents being harbored and therefore predispose the scavenging chickens to the agents. Humans may similarly be exposed, and the resultant effect may be the interspecies exchange of Brucella infections between humans and animals with the associated health problems and economic losses.

\section{Conclusion}

Avian brucellosis remains unabated in Anambra State, Nigeria, with the same seroprevalence of 3\% earlier reported 30 years ago. Sex (females), husbandry system (free range), breed (indigenous chicken), and mixed farming are the major determinants of avian brucellosis. Potent risk factors for human Brucella infection at the animal-human interface are non-use of PPC, poor awareness of brucellosis and its method of spread or control, cohabitation with animals, eating while on duty and paltry educational level. There is urgent need for an effective control or eradication program against brucellosis in the study area, using a coordinated One Health approach considering multifaceted factors behind the disease. Such a program must work toward the eradication of the animal disease, of which avian brucellosis is cardinal, as this is the key to the control or eradication of human brucellosis. Although low, the obtained prevalence should be taken very seriously in view of the devastating public health problems, and enormous economic consequences associated with brucellosis in both human and animal populations as Brucella organisms were detected in milk from a seronegative cow [34].

\section{Recommendations}

To limit interspecies transmission of Brucella agents, it is recommended that the rearing of different animal species (cattle, sheep, pigs, goats, poultry, etc.) together especially under the extensive management system should be avoided. Public awareness campaign against brucellosis and mass education of farmers on the dynamics of the disease transmission and methods of prevention should be intensified. Mass vaccination campaign, targeting all animal species, with the available brucellosis vaccines (Rev. 1 and S19 stains) as against the current practice that targets only cattle with $B$. abortus vaccine is recommended. Finally, we advocate provision of PPC to occupationally at-risk individuals for compulsory use while on duties with tough sanctions against defaulters to limit human Brucella infection from animal sources.

\section{Authors' Contributions}

JIO and EON conceived and designed the study. UJN, EE, and SOE collected serum samples and screened them for Brucella antibodies under the supervision of JIO. UJN designed the questionnaire and carried out the survey alongside SOE and EE. EON and JIO drafted and edited the manuscript. All authors read and approved the final manuscript.

\section{Acknowledgments}

The authors appreciate the efforts of the laboratory technologists at the Veterinary Public Health and Preventive Medicine Laboratory, University of Nigeria, Nsukka, for their assistance during the Brucella antibody screening. The authors did not receive financial assistance from any source but funded this study exclusively.

\section{Competing Interests}

The authors declare that they have no competing interests.

\section{References}

1. Alton GG, Jones LM, Angus RD, Verger JM. Techniques for the Brucellosis Laboratory. Paris: Institute National de la Recherche Agronomique; 1988. p. 192-5.

2. Onunkwo JI, Njoga EO, Nwanta JA, Shoyinka SV, Onyenwe IW, Eze JI. Serological survey of porcine Brucella infection in Southeast, Nigeria. Nigerian Vet J 2011;32:60-2.

3. Adamu NB, Adeniyi SO, Adamu SG, Bale JO, Okoh AE, Umaru GA, et al. Seroprevalence of brucellosis among livestock workers at Maiduguri cattle market, Borno State, North Eastern, Nigeria. J Pub Health Epidemiol 2015;7:253-7.

4. Adamu NB, Adamu SG, Jajere MS, Atsanda NN, Mustapha FB, Maina M. Serological Survey of Brucellosis in Slaughtered Local Chickens, Guinea Fowls, Ducks and Turkey in North-Eastern Nigeria. Int J Poultry Sci 2014;13:340-2.

5. Ior DD, Chukwu CC, Oche DA, Semaka AA. Serological evidence for Brucella infection in chickens in Benue State, North Central Nigeria. Continental J Anim Vet Res 2013;5:31-6.

6. Bale JO, Nuru S. Serological study of brucellosis in local fowls in Northern Nigeria. J Anim Prod Res 1982;2:53-62.

7. Chukwu CC, Anene BM. Serological Evidence of Avian Brucellosis in Anambra State, Nigeria. Zariya Vet 1988;3:36-9.

8. Agada CA, Ogugua AJ, Anzaku EJ. Occurrence of brucellosis in small ruminants slaughtered in Lafia central abattoir, Nasarawa State, Nigeria. Sokoto J Vet Sci 2018;16:16-23.

9. Bamaiyi PH. Prevalence and risk factors of brucellosis in man and domestic animals: A review. Int J One Health 2016;2:29-34.

10. Njoga EO, Onunkwo JI, Okoli CE, Ugwuoke WI, Nwanta JA, Chah KF. Assessment of antimicrobial drug administration and antimicrobial residues in food animals in Enugu State, Nigeria. Trop Anim Health Prod 2018;50:897-902.

11. Junaidu AU, Salihu MD, Ahmed F, Ambursa MA, Gulumbo MI. Brucellosis in local chicken in Northern Nigeria Int J Poultry Sci 2006;5:547-9.

12. Adamu M, Mshelia GD, Elelu N, Ouda L, Egwu GO. Studies on farmer awareness on caprine abortion and the presence of Brucella abortus and Brucella melitensis in selected flocks in an arid zone of Nigeria. J Vet Med Health 2012;4:17-21.

13. Adesokan HK, Alabi PI, Stack JA, Cadmus SI. Knowledge and practices related to bovine brucellosis transmission amongst livestock workers in Yewa, South-western Nigeria. J South Afr Vet Assoc 2013;84:121-5.

14. Ducrotoy M, Bertu WJ, Matope G, Cadmus S, CondeÁlvarez R, Gusi AM, et al. Brucellosis in Sub-Saharan Africa: Current challenges for management, diagnosis and control. Acta Trop 2017;165:179-93.

15. Ducrotoy MJ, Bertu WJ, Ocholi RA, Gusi AM, Bryssinckx W, Welburn S, et al. Brucellosis as an emerging threat in developing economies: Lessons from Nigeria. PLoS Negl Trop Dis 2014;8:e3008. 
16. Jajere SM, Atsanda NN, Bitrus AA, Hamisu TM, Ayo AO. Seroprevalence of brucellosis among cattle slaughtered in three municipal abattoirs of Gombe state, Northeastern Nigeria. Vet World 2016;9:1082-6.

17. Kaltungo BY, Saidu SN, Sackey AK, Kazeem HM. Seroprevalence of brucellosis in sheep in North Senatorial District of Kaduna, Nigeria. Asian Pac J Trop Dis 2015;5:163-8.

18. Shehu LM, Ehitade EC. Serological survey of brucellosis in local chickens, guinea fowl, ducks and turkey in Bauchi and Environs. Nig Vet J 1999;20:4747-50.

19. Gugong VT, Maurice NA, Ngbede EO, Hambolu SM, Ajogi I. Serological evidence of brucellosis in local chickens in Kaduna State, Nigeria. J Anim Vet Adv 2012;11:418-9.

20. Kudi AC, Kalla DJ, Kudi MC, Yusuf H. Serological survey of brucellosis in traditionally managed domestic fowl in northern Guinea Savannah, Nigeria. World's Poultry J 1997;53:287-28.

21. Reddy D1, Singh DK, Mantur BG, Kumar A, Kumari G, Rajagunalan S, et al. Seroepidemiology of human brucellosis in Karnataka. J Vet Pub Hlth 2014;12:113-5.

22. Cadmus SI, Ijagbone IF, Oputa HE, Adesokan HK, Stack JA. Serological survey of brucellosis in livestock animals and workers in Ibadan Nigeria. Afr J Biomed Res 2006;9:163-8.

23. Aworh MK, Okolocha E, Kwaga J, Fasina F, Lazarus D, Suleman I, et al. Human brucellosis: Seroprevalence and associated exposure factors among abattoir workers in Abuja, Nigeria. Pan Afr Med J 2013. DOI: 10.11604/ pamj.2013.16.103.2143.

24. Dean AS, Crump L, Greter H, Schelling E, Zinsstag J. Global burden of human brucellosis: A systematic review of disease frequency. PLoS Negl Trop Dis 2012;6:e1865.

25. Kaltungo BY, Saidu SN, Sackey AK, Kazeem HM. A review on diagnostic techniques for brucellosis. Afr J Biotechnol
2014;13:1-10.

26. Pappas G, Panagopoulou P, Christou L, Akritidis N. Brucella as a biological weapon. Cell Mol Life Sci 2006;63:2229-36

27. Njoga EO, Onunkwo JI., Ekere SO., Njoga UJ., Okoro WN. Seroepidemiology of equine brucellosis and role of horse carcass processors in spread of Brucella infection in Enugu State, Nigeria 2018; Int. J. Curr. Res. Rev., 10:39-45.

28. Khan AQ, Haleem SK, Shafiq M, Khan NA, Rahman S. Seropositivity of brucellosis in human and livestock in Tribal-Kurram Agency of Pakistan indicates cross circulation. Thai J Vet Med 2017;47:349-55.

29. McDermott J, Grace D, Zinsstag J. Economics of brucellosis impact and control in low-income countries. Rev Sci Tech OIE (International Office of Epizootics) 2013;32:249-61.

30. Ogugua AJ, Akinseye OV, Ayoola MC, Stack J, Cadmus SI. Risk factors associated with brucellosis among slaughtered cattle: Epidemiological insight from two metropolitan abattoirs in Southwestern Nigeria. Asian Pac J Trop Dis 2015;5:747-53.

31. Samakabadi EK, Mushi EZ, Basupang K, Binta MG. Brucella abortus antibodies in the sera of indigenous chickens around Gaborone, Botswana. J Anim Vet 2008;7:1610-2.

32. Nabirye HM, Erume J, Nasinyama GW, Kungu JM, Nakavuma J, Ongeng D, et al. Brucellosis: Community, medical and veterinary workers' knowledge, attitudes, and practices in Northern Uganda. Int $\mathrm{J}$ One Health 2017;3:12-8.

33. Petersen E, Rajashekara G, Sanakkayala N, Eskra L, Harms J, Splitter G. Erythritol triggers expression of virulence traits in Brucella melitensis. Microb Infect 2013;15:440-9.

34. Sabrina R, Taha MH, Bakir M, Asma M, Khaoula B. Detection of Brucella spp. in milk from seronegative cows by real-time polymerase chain reaction in the region of Batna, Algeria. Vet World 2018;11:363-7. 